\title{
Acid mine drainage in semi-arid regions: The extent of the problem in the waters of reservoirs in the Iberian Pyrite Belt (SW S....
}

Article in Hydrology Research · January 2015

DOI: $10.2166 /$ nh. 2013.086

CITATIONS

6

5 authors, including:

\section{Maria Santisteban}

Universidad de Huelva

42 PUBLICATIONS 166 CITATIONS

SEE PROFILE

\section{María Luisa De la Torre Sanchez}

Universidad de Huelva

74 PUBLICATIONS 1,159 CITATIONS

SEE PROFILE
READS

182
Jose Antonio Grande

Universidad de Huelva

91 PUBLICATIONS 1,306 CITATIONS

SEE PROFILE

Teresa Valente

University of Minho

82 PUBLICATIONS 431 CITATIONS

SEE PROFILE

Some of the authors of this publication are also working on these related projects:

RADIONUCLIDES RELEASES FROM PHOSPHOGYPSUM STACKS, DISPERSION ASSESMENT, RADIOLOGICAL RISKS AND REMEDIATION PROPOSALS View project 


\title{
Acid mine drainage in semi-arid regions: the extent of the problem in the waters of reservoirs in the Iberian Pyrite Belt (SW Spain)
}

\author{
M. Santisteban, J. A. Grande, M. L. de la Torre, T. Valente and J. C. Cerón
}

\begin{abstract}
$\overline{\text { ABSTRACT }}$
There are many reservoirs in the Iberian Pyrite Belt (IPB), SW Spain, which receive contributions from watercourses affected by acid mine drainage processes, characterised by low pH values and high concentrations of heavy metals and sulphates. When they reach the reservoirs, the waters increase its $\mathrm{pH}$, which will cause most of the metal load carried by the mining channel to precipitate into the reservoir itself and accumulate on its floor. The silting of reservoirs is an environmental problem which can affect the loss of storage capacity, their general functioning and aquatic ecosystems. A study of these is vital to allow both preventative and corrective measures to be established. Climatic conditions are the most significant external controlling factors in terms of the degree and type of mining pollution. The study area presents characteristics typical of the semi-arid Mediterranean climate, with annual precipitation of around $630 \mathrm{~mm} /$ year; moderate temperatures with average annual values of $17.1^{\circ} \mathrm{C}$ and a temperature range of $50{ }^{\circ} \mathrm{C}$. The aim of this study is to carry out a physical-chemical characterization of the waters where they enter the reservoirs located in the IPB over the course of a hydrological year and to establish possible interdependencies between the

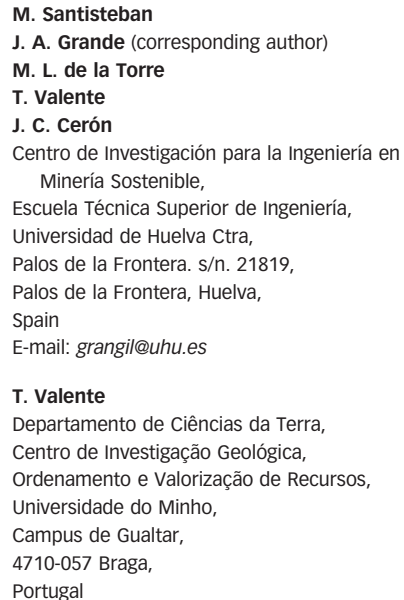

Key words | acid mine drainage, Iberian Pyrite Belt, metals, mine, mining pollution, reservoirs

\section{INTRODUCTION}

At present, the silting of reservoirs is an environmental problem of the highest order, which goes beyond the loss of storage capacity and can affect their general functioning as aquatic ecosystems.

The silting of reservoirs gives rise to a series of wellknown effects, from a loss of water storage capacity to a change in the longitudinal slope of the channel, the formation of wetlands, a limitation in recreational use or a tendency towards the eutrophication of their waters. However, the silting of a reservoir also leads to a clear loss of efficiency in the reservoir itself with the corresponding cost that affects both the profitability of the initial investment in the actual hydrological engineering, and the operating accounts (Palau 2002).

Spread throughout the Iberian Pyrite Belt (IPB) are numerous reservoirs intended for industrial, agricultural or recreational use. Many of these reservoirs are located in watercourses affected by acid mine drainage (AMD) processes, which means that the water that reaches the dams is low in $\mathrm{pH}$ and has a high metal and sulphate load. When the mine-water contributions arrive at the reservoir, there is a sharp increase in the $\mathrm{pH}$ of the acid waters upon encountering the huge volume of the receiving basin. This increase in $\mathrm{pH}$ is translated into a violent reduction in the dissolving capacity of the mixing waters, which causes most of the metal load carried by the mining watercourse to precipitate into the reservoir itself. In any case, the metal precipitate accumulates in the form of sediment on the floor of the dam, always remaining subject to variations in the $\mathrm{pH}$ of the medium and redox potential, which can lead 
to silting of the sedimentary medium (Grande et al. 2005a).

The newly formed metal sulphides that accumulate in the sediment and the particulate matter containing sulphates transported by mining effluent are a potential environmental risk because they can oxidise rapidly and release metals, producing a greater increase in the acidity of the medium. Variations in $\mathrm{pH}$ and oxygen are the greatest factors that affect the mobility of trace metals (Wen \& Allen I999). Oxidation of the sediment on the floor can occur during periods of rotation (periods of oxygenation) and is also due to remobilisation and transport during high rainfall events and strong water currents.

The impact of the climate on the polluting process of AMD as it affects pyritic materials exposed on the surface is more than well known. Climatic conditions, and especially precipitation, are the most significant external controlling factors in terms of the degree and type of mining pollution in any area.

The study area presents characteristics typical of the semi-arid Mediterranean climate, with annual precipitation of around $630 \mathrm{~mm} /$ year; moderate temperatures with average annual values of $17.1^{\circ} \mathrm{C}$ and a temperature range of roughly $50{ }^{\circ} \mathrm{C}$. The precipitation occurs principally in the autumn and winter months, producing situations of drought in summer and part of the spring.

In semi-arid climates, the construction of dams is one of the most common alternatives to cover the water needs of the population and industry. The vulnerability of these surface waters to pollution is much greater than that of underground waters (Grande et al. 20I0a).

The scientific literature is replete with numerous studies aimed at quantifying the environmental effects of AMD in water, from the point of view of the processes that take place in the affected waters (Grande 20II; Grande et al. 2000, 2003a, b, 2005a, b, 2010a, b, c, d, e, 20II; Younger 200I; Sáinz et al. 2003; Sarmiento 2007; Cánovas et al. 2008; de la Torre et al. 2009; Hubbard et al. 2009; Jiménez et al. 2009; Egal et al. 20I0; Loredo et al. 20Io; Ochieng et al. 20I0; Romero et al. 20II); the sediments (Borrego et al. 2002; López-González et al. 2006; Vicente-Martorell et al. 2008; Ruiz et al. 2009; Couceiro \& Schettini 20Io) or the biota (Valente \& Leal Gomes 2007; Casiot et al. 2009; Gray \& Delaney 20I0;
Gunn et al. 20I0; Hafs et al. 20I0; Hao et al. 20Iо; Amaral-Zettler et al. 20II).

\section{GEOGRAPHICAL AND GEOLOGICAL LOCATION}

The study area that the present work focuses on is located in the IPB, in the southwest of the Iberian Peninsula, containing a total of 23 reservoirs spread mainly along the basins of the rivers Tinto and Odiel (Figure 1), which are the main watercourses affected by AMD, and the river basins of the Chanza and the Guadiamar, which are affected to a lesser extent.

The Odiel, which belongs to the Andalusian Atlantic Basin, rises in Marimateos at an altitude of $660 \mathrm{~m}$ in the Aracena mountains and covers more than $140 \mathrm{~km}$ before losing its fluvial nature in Gibraleón, where it has its confluence with the River Tinto in what is known as the 'Marismas del Odiel', an estuary complex of salt marshes with great ecological value declared a Biosphere Reserve by UNESCO. The River Tinto belongs to the Guadiana basin, rises in the Padre Caro mountains, in the district of Nerva, and covers almost $100 \mathrm{~km}$ to its mouth. Both rivers have a natural torrent and are located in a climate zone with extremely irregular rainfall (Sáinz et al. 2003). Their waters descend towards the zone of tidal influence with an average $\mathrm{pH}$ of less than 2.5 and an enormous dissolved metal load. In a single day the River Odiel carries more heavy metals into the Atlantic shelf than the total released by the Aznalcollar disaster (Sáinz et al. 2003).

The rivers Tinto and Odiel have been widely studied by a number of authors: Borrego et al. (2002); Braungardt et al. I998, 2003; Davis et al. 2007; Elbaz-Poulichet et al. (I999, 2000, 200I); Grande 20II; Grande et al. 2000, 2003a, b, 2005a, b, 20I0a, b, c, d, e, 20I; Leblanc et al. (2000); Sáinz (I999); Sáinz et al. (2000a, b, c, 2002, 2003, 2004, 2005); de la Torre et al. (2009); Jiménez et al. (2009).

The IPB is a geological formation that is $230 \mathrm{~km}$ long and on average $50 \mathrm{~km}$ wide, and constitutes one of the largest deposits of sulphides in the world (Leistel et al. 1998) with approximately 1,700 MT of reserves. These massive bodies of sulphides contain pyrite, with which sphalerite, galena and chalcopyrite and many minor phases are associated (Sáez et al. 1999). These deposits have been exploited 


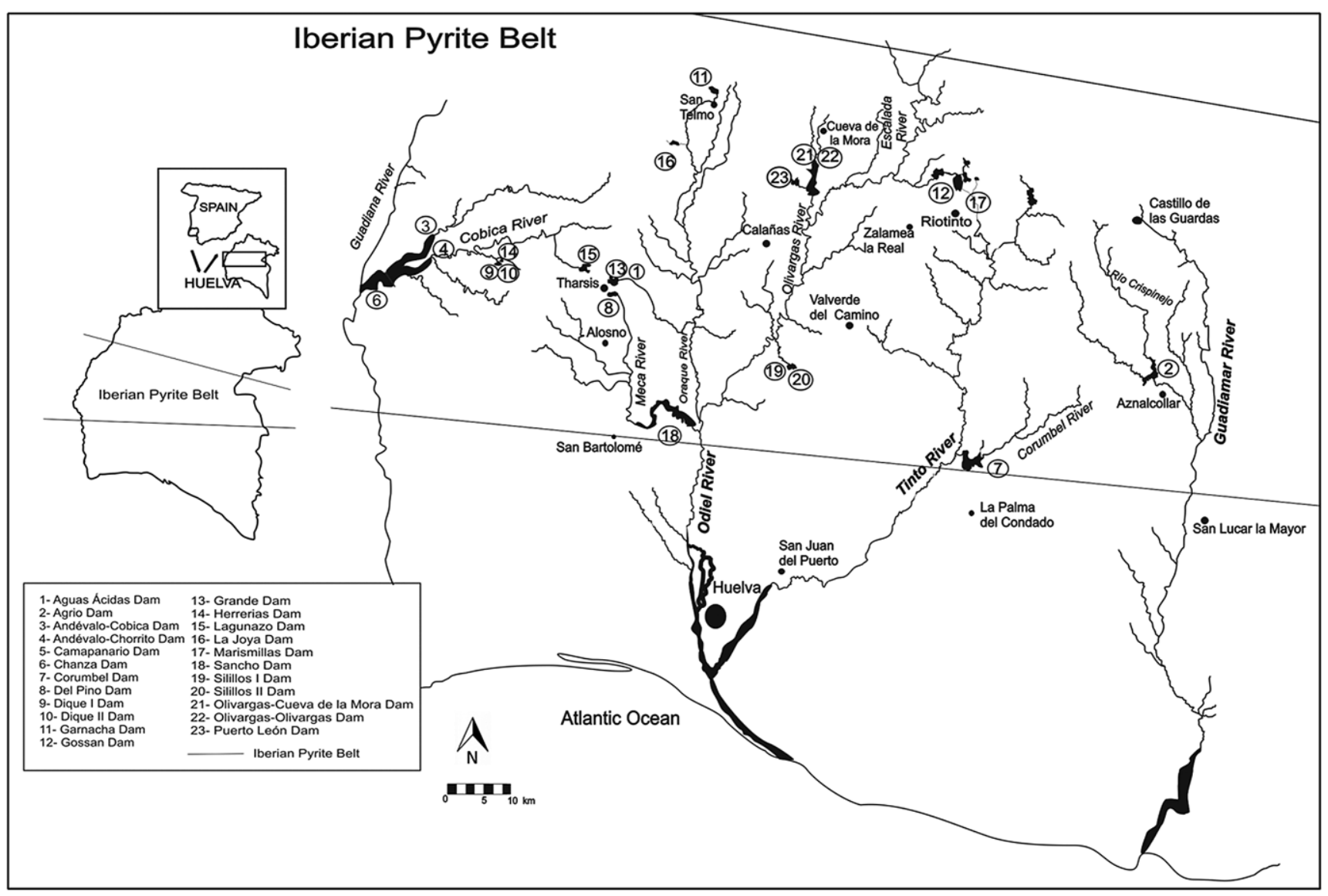

Figure 1 | Location map of the sampled dams.

for more than 2000 years, with numerous extensive mining workings remaining as evidence of this activity, as well as several million tonnes of ancient slag of various composition (Pinedo Vara 1963). The waters which emerge from inside the mines through the tunnels, leachate from slag heaps, mountains of ash, pools, cementation channels and calcination areas, run-off from washing pyrite residue, low-grade sulphur ore, slag and pyrite ash spread by the mines, all produce liquid pollution, which, once it has reached the closest watercourses, enters the main course of the rivers Tinto and Odiel by means of a network of tributaries and sub-tributaries (Sáinz et al. 200oc).

The merging of acid drainage from these mines, most of them abandoned and unrestored, with the drainage network is responsible for modifying the physical-chemical characteristics of the watercourses, increasing the acidity of the waters and their heavy-metal and sulphate content, as well as the concentration of metals in their sediment to extreme levels (USEPA 1994; Lyew \& Sheppard 200r; Grande et al. 2005b).

\section{OBJECTIVES}

The concentration of metals and sulphates in a mining river close to the productive source is 10 times greater than the concentrations measured in the same river near its mouth, above the limit of tidal influence (Grande et al. 2005b). This fact suggests that there are precipitation processes along the watercourse and when it reaches the reservoir, which change the hydrochemical conditions.

Depositing of the materials carried by the water currents occurs in the reservoirs. In this case, both the bed load and the load in suspension are deposited, but the dissolved load (including the microcolloidal fraction) could even be carried outside the reservoir by the water it releases. The presence of 
significant quantities of organic matter in this sediment is due to the depletion of oxygen and the reduction of sulphates by sulphate-reducing bacteria (Heijs \& Van Gemerden 2000). The sulphide produced by the reduction of sulphates can react chemically with the metals to form insoluble sulphides, such as $\mathrm{FeS}, \mathrm{FeS}_{2}, \mathrm{ZnS}$, etc. (Rickard \& Morse 2005). The newly formed metal sulphides accumulate in the sediment, forming a potential risk from an environmental point of view, because they can oxidise and release metals, producing a greater increase in the acidity of the medium.

The present study aims to carry out a physical-chemical characterisation of the waters where they enter the reservoirs in the IPB affected by AMD over the course of the hydrological year 2011-2012 and to establish possible relations.

\section{MATERIALS AND METHODS}

The sampling phase was carried out on a 2-weekly basis in the period between October 2011 and May 2012 during the period of rainfall which causes the water to flow in the watercourses, with the sampling finishing once the channels in the sector being studied have stopped running. During this period we simultaneously proceeded with analysis of the samples in the laboratory, using a variety of analytical techniques.

Once the study area had been delimited and the water relations were understood, both in terms of natural watercourses and contributions from mining leachates, the next step was to determine the points at which the water samples would be taken. A sampling point was chosen where the waters enter the reservoirs affected by AMD, and which is covered by the waters during the measuring period, close to the maximum capacity limit of the dams. The reservoirs to be sampled are gathered together in Table 1 and Figure 1.

During the sampling campaign, determination of $\mathrm{pH}$, electrical conductivity (EC) and total dissolved solids (TDS) was carried out in situ using a Crison MM40 portable multimeter.

Following the measurements in the field, two water samples were taken in sterilised polyethylene containers at each point, one to determine the sulphates and another to determine the heavy metals. Nitric acid was added to obtain a $\mathrm{pH}<2$ in order to prevent the precipitation of the metals during transportation to the laboratory, which was carried out in 100 and $200 \mathrm{~mL}$ PVC containers, respectively, in a portable refrigerator at a temperature of $4{ }^{\circ} \mathrm{C}$.

In the laboratory, the water samples were vacuum-filtered using 0.45 micron cellulose nitrate filters (Sartorius 11406-47-ACN).

Once filtered, the water samples were stored in hermetically sealed polyethylene containers in a refrigerator at a temperature of between 1 and $4{ }^{\circ} \mathrm{C}$.

All the reagents used were analytical grade or of Suprapur quality (Merck, Darmstadt, Germany). The standard solutions were Merck AA Certificate. Milli-Q water was used in all the experiments. The water distiller used was the Optic Ivymen System AC-L4.

A Macherey-Nagel PF-11 photometer was used to determine sulphate concentration.

The equipment used to carry out the metals analysis was a Perkin-Elmer AAnalyst 800 atomic absorption spectrophotometer equipped with a graphite furnace and an air/ acetylene-flame atomiser. The samples were introduced using the Perkin-Elmer AS800 Autosampler. Perkin-Elmer Lumina $^{\mathrm{TM}}$ hollow cathode lamps (HDL and LDL) were used as sources of radiation.

The data from the analytics, as well as the parameters measured in the field, were submitted to graphical/statistical treatment in order to apply cluster analysis, which allows approximation dendrograms to be obtained using the STATGRAPHICS Centurion XVI.I software package.

\section{RESULTS}

\section{Physical-chemical characterisation}

Based on measurement of the physical-chemical parameters and analyses of metals and sulphates carried out in the laboratory, a huge volume of data was obtained, with the average values gathered together in Tables 2 and 3 .

It can be observed that the $\mathrm{pH}$ ranges from 2.18, being the minimum value recorded, to values close to neutral, with 6.66 being the maximum value. The average $\mathrm{pH}$ values measured at the various sampling points were as follows: 
Table 1 | General data of the sampled dams

\begin{tabular}{|c|c|c|c|c|c|c|c|}
\hline \multirow[b]{2}{*}{ Points } & \multirow[b]{2}{*}{ Dams } & \multicolumn{2}{|c|}{ Coordinates UTM } & \multirow[b]{2}{*}{ Uses } & \multirow[b]{2}{*}{ Volume $\left(\mathrm{hm}^{3}\right)$} & \multirow[b]{2}{*}{ Surface (ha) } & \multirow[b]{2}{*}{ River location } \\
\hline & & $\mathbf{x}$ & $\mathbf{Y}$ & & & & \\
\hline 1 & Andévalo-Cobica & 650,803 & $4,167,417$ & - & 634 & 3,630 & Cobica \\
\hline 2 & Andévalo-Chorrito & 649,240 & $4,165,762$ & - & 634 & 3,630 & Chorrito \\
\hline 3 & Agrio & 738,737 & $4,161,112$ & Supply, industrial & 20.37 & 192.2 & Agrio \\
\hline 4 & A. ácidas & 666,964 & $4,163,520$ & - & - & 1.16 & - \\
\hline 5 & Chanza & 637,578 & $4,173,754$ & Supply, fishing, irrigation & 341 & 2,239 & Chanza \\
\hline 6 & Campanario & 691,692 & $4,155,967$ & Recreation & - & 4 ha & Aguas Agrias \\
\hline 7 & Corumbel & 717,217 & $4,147,612$ & Supply, irrigation & 19 & 396 & Corumbel \\
\hline 8 & Del Pino & 666,784 & $4,162,493$ & - & - & 1.9 & Rivera de la Angustinos \\
\hline 9 & Dique I & 651,528 & $4,164,736$ & - & - & 7.7 & - \\
\hline 10 & Dique II & 651,387 & $4,165,068$ & - & - & 3 & - \\
\hline 11 & Herrerias & 651,471 & $4,165,235$ & - & - & 5 & Chorrito \\
\hline 12 & Garnacha & 678,806 & $4,186,885$ & Supply, industrial & 6.5 & 3 & - \\
\hline 13 & Gossan & 712,690 & $4,179,052$ & Mining, industrial & 2,200 & 125 & - \\
\hline 14 & Grande & 666,764 & $4,163,634$ & - & - & 24.28 & Aguas Agrias \\
\hline 15 & Lagunazo & 662,731 & $4,165,639$ & Industrial, fishing & 3 & 18 & Cobica \\
\hline 16 & La Joya & 673,647 & $4,180,222$ & Industrial & - & - & - \\
\hline 17 & Marismillas & 715,238 & $4,175,219$ & Industrial & - & 18 & Tinto \\
\hline 18 & Silillos I & 700,515 & $4,162,637$ & Supply, fishing, recreation & 1.05 & 28 & Buitrón \\
\hline 19 & Silillos II & 701,078 & $4,161,423$ & Supply & - & 8 & - \\
\hline 20 & Sancho & 670,111 & $4,147,929$ & Supply, industrial & 58 & 427 & Meca \\
\hline 21 & Olivargas & 692,476 & $4,182,511$ & - & 29 & 240 & Olivargas \\
\hline 22 & Cueva de la Mora & 693,586 & $4,180,337$ & - & 29 & 240 & Barranco de la Malena \\
\hline 23 & Puerto León & 689,958 & $4,176,833$ & Fishing, supply, industrial & 11 & 19 & Naranjo \\
\hline
\end{tabular}

Marismillas < Aguas Ácidas $<$ Gossan $<$ Cueva de la Mora $<$ Andévalo Cobica $<$ Sancho $<$ Del Pino (3.64) $<$ Andévalo Chorrito $(3.65)<$ Grande $<$ Olivargas $<$ Silillos II $<$ Agrio $<$ Lagunazo (5.64) $<$ Campanario $<$ Puerto León $<$ Garnacha $=$ Corumbel $<$ Silillos $\mathrm{I}<$ Chanza $<$ La $\quad$ Joya $<$ Dique I $<$ Dique II $<$ Herrerías.

The maximum TDS and electrical conductivity values recorded were $3,120.78 \mu \mathrm{S} / \mathrm{cm}$ and $5,849.31 \mathrm{mg} / \mathrm{L}$, respectively, both measured in the Marismillas reservoir. The minimum values for these parameters could be measured in the La Joya reservoir, with a value of $141.74 \mu \mathrm{S} / \mathrm{cm}$ for electrical conductivity and $90.69 \mathrm{mg} / \mathrm{L}$ for TDS.

The average concentrations of electrical conductivity measured in the various reservoirs were in the following order: Aguas Ácidas > Marismillas > Gossan > Cueva de la
Mora $>$ Olivargas $>$ Andévalo-Cobica $>$ Sancho $>$ AndévaloChorrito $>$ Herrerías $>$ Grande $>$ Lagunazo $>$ Chanza $>$ Agrio $>$ Del Pino $>$ Corumbel $>$ Campanario $>$ Dique II $>$ Puerto León $>$ Silillos I $>$ Garnacha $>$ Dique $\quad$ I $>$ Silillos $\quad$ II $>$ La Joya.

The highest average concentration recorded for TDS was in the Marismillas reservoir, followed by the Aguas Ácidas reservoir $>$ Gossan $>$ Cueva de la Mora $>$ Olivargas $>$ Andévalo-Cobica $>$ Sancho $>$ Andévalo-Chorrito $>$ Herrerías $>$ Grande $>$ Lagunazo $>$ Chanza $>$ Agrio $>$ Del Pino $>$ Dique II $>$ Campanario $>$ Garnacha $>$ Silillos II $>$ Dique I $>$ La Joya.

As regards the sulphates analysed, the maximum concentration obtained was $3,086.35 \mathrm{mg} / \mathrm{L}$ in the Aguas Ácidas reservoir, while the minimum concentration was 


\begin{tabular}{|c|c|c|c|c|c|c|}
\hline Points & Dams & $\begin{array}{l}\mathrm{pH} \\
n=17\end{array}$ & $\begin{array}{l}T(C) \\
n=17\end{array}$ & $\begin{array}{l}\mathrm{EC}(\mu \mathrm{S} / \mathrm{cm}) \\
n=17\end{array}$ & $\begin{array}{l}\text { TDS (mg/L) } \\
n=17\end{array}$ & $\begin{array}{l}\mathrm{SO}_{4}^{2-}(\mathrm{mg} / \mathrm{L}) \\
n=17\end{array}$ \\
\hline 1 & Aguas Ácidas & 2.47 & 14.17 & $6,074.16$ & $3,890.27$ & $3,086.35$ \\
\hline 2 & Agrio & 5.52 & 16.20 & 321.99 & 205.83 & 137.24 \\
\hline 3 & Andévalo-Cobica & 3.07 & 17.48 & 956.88 & 612.41 & 426.35 \\
\hline 4 & Andévalo-Chorrito & 3.65 & 17.34 & 652.19 & 417.12 & 412.00 \\
\hline 5 & Camapanario & 5.66 & 13.08 & 265.83 & 171.51 & 53.65 \\
\hline 6 & Chanza & 5.89 & 17.59 & 346.32 & 221.56 & 30.06 \\
\hline 7 & Corumbel & 5.84 & 16.72 & 266.59 & 170.40 & 2.18 \\
\hline 8 & Del Pino & 3.65 & 15.81 & 300.56 & 189.39 & 126.88 \\
\hline 9 & Dique I & 5.97 & 18.19 & 183.61 & 116.89 & 9.59 \\
\hline 10 & Dique II & 6.23 & 19.07 & 245.67 & 158.97 & 25.53 \\
\hline 11 & Garnacha & 5.84 & 16.83 & 197.18 & 126.54 & 72.29 \\
\hline 12 & Gossan & 2.64 & 16.65 & $2,633.00$ & $1,657.68$ & $1,415.71$ \\
\hline 13 & Grande & 4.04 & 15.02 & 483.63 & 308.97 & 209.82 \\
\hline 14 & Herrerias & 6.66 & 19.57 & 559.47 & 362.28 & 71.12 \\
\hline 15 & Lagunazo & 5.64 & 17.61 & 406.72 & 260.07 & 127.41 \\
\hline 16 & La Joya & 5.93 & 19.12 & 141.74 & 90.69 & 6.18 \\
\hline 17 & Marismillas & 2.18 & 17.51 & $3,120.78$ & $5,849.31$ & $2,168.00$ \\
\hline 18 & Sancho & 3.34 & 17.65 & 793.32 & 505.39 & 323.88 \\
\hline 19 & Silillos I & 5.85 & 14.02 & 206.88 & 155.66 & 23.18 \\
\hline 20 & Silillos II & 5.02 & 15.37 & 168.44 & 123.49 & 29.00 \\
\hline 21 & Olivargas & 4.74 & 16.14 & $1,099.63$ & 704.16 & 494.65 \\
\hline 22 & Cueva de la Mora & 2.72 & 15.49 & $2,088.14$ & $1,308.88$ & $1,167.18$ \\
\hline 23 & Puerto León & 5.74 & 17.22 & 227.73 & 167.94 & 46.29 \\
\hline
\end{tabular}

$2.18 \mathrm{mg} / \mathrm{L}$ in the Corumbel reservoir. The order of abundance in the other reservoirs was: Aguas Ácidas $>$ Marismillas $>$ Gossan $>$ Cueva de la Mora $>$ Olivargas $>$ Andévalo-Cobica $>$ Andévalo-Chorrito $>$ Sancho $>$ Grande $>$ Agrio $>$ Lagunazo $>$ Del Pino $>$ Garnacha $>$ Herrerías $>$ Campanario $>$ Puerto León $>$ Chanza $>$ Silillos II $>$ Dique II $>$ Silillos I $>$ Dique I $>$ La Joya $>$ Corumbel.

If we look at the summation of the average concentrations of metals analysed we see that the Marismillas reservoir presents the highest value with $2,601.24 \mathrm{mg} / \mathrm{L}$ of total average metals. The Aguas Ácidas and Cueva de la Mora reservoirs also present very high values, 384.95 and $149.64 \mathrm{mg} / \mathrm{L}$, respectively. The lowest recorded value was $1.27 \mathrm{mg} / \mathrm{L}$ for the Dique I reservoir. The order of abundance for the rest of the reservoirs was: Gossan $>$ Andévalo-Cobica $>$ AndévaloChorrito $>$ Sancho $>$ Olivargas $>$ Grande $>$ Puerto León $>$
Silillos I $>$ Campanario $>$ Del Pino $>$ Agrio $>$ Lagunazo $>$ La Joya $>$ Silillos II $>$ Herrerías $>$ Dique II $>$ Corumbel $>$ Garnacha $>$ Chanza.

Figures 2(a) and b presented below show the distribution of the values for the physical-chemical parameters and the sulphates measured in each reservoir. Three groups clearly stand out: those reservoirs which present high $\mathrm{pH}$ values and low values for the other parameters (TDS, EC, sulphates and $\sum$ metals), intermediate values for $\mathrm{pH}$ and the other values, and low $\mathrm{pH}$ values and high values for the other parameters.

\section{Cluster analysis}

With the aim of establishing possible relationships between the variables for a single reservoir, the mass of 
Table 3 Average values for the analysed metals and sulphates

\begin{tabular}{|c|c|c|c|c|c|c|c|c|c|c|c|c|c|}
\hline Points & Dams & $\begin{array}{l}\mathrm{Fe}(\mathrm{mg} / \mathrm{L}) \\
n=17\end{array}$ & $\begin{array}{l}\mathrm{Cu} \\
(\mathrm{mg} / \mathrm{L}) \\
n=17\end{array}$ & $\begin{array}{l}\mathrm{Zn} \\
(\mathrm{mg} / \mathrm{L}) \\
n=17\end{array}$ & $\begin{array}{l}\text { Mn } \\
\text { (mg/L) } \\
n=17\end{array}$ & $\begin{array}{l}\text { Cd } \\
(\mathrm{mg} / \mathrm{L}) \\
n=17\end{array}$ & $\begin{array}{l}\text { Ni } \\
\text { (mg/L) } \\
n=17\end{array}$ & $\begin{array}{l}\text { Co }(\mathrm{mg} / \mathrm{L}) \\
n=17\end{array}$ & $\begin{array}{l}\text { As } \\
(\mathrm{mg} / \mathrm{L}) \\
n=17\end{array}$ & $\begin{array}{l}\text { Sb } \\
(\mathrm{mg} / \mathrm{L}) \\
n=17\end{array}$ & $\begin{array}{l}\mathrm{Pb} \\
(\mathrm{mg} / \mathrm{L}) \\
n=17\end{array}$ & $\begin{array}{l}\text { Al } \\
(\mathrm{mg} / \mathrm{L}) \\
n=17\end{array}$ & $\Sigma$ \\
\hline 1 & Aguas Ácidas & 315.82 & 9.05 & 20.10 & 34.03 & 0.11 & 1.22 & 3.54 & 0.34 & 0.01 & 0.59 & 0.15 & 384.95 \\
\hline 2 & Agrio & 0.46 & 0.18 & 0.16 & 1.34 & 0.07 & 0.03 & 0.05 & 0.00 & 0.00 & 0.25 & 0.48 & 3.02 \\
\hline 3 & $\begin{array}{c}\text { Andévalo- } \\
\text { Cobica }\end{array}$ & 34.83 & 1.39 & 2.31 & 3.10 & 0.16 & 0.08 & 0.09 & 0.05 & 0.00 & 0.30 & 0.53 & 42.84 \\
\hline 4 & $\begin{array}{l}\text { Andévalo- } \\
\text { Chorrito }\end{array}$ & 11.59 & 2.19 & 2.63 & 6.41 & 0.26 & 0.17 & 0.22 & 0.00 & 0.01 & 0.30 & 0.55 & 24.34 \\
\hline 5 & Camapanario & 0.46 & 0.09 & 0.10 & 2.36 & 0.13 & 0.04 & 0.05 & 0.00 & 0.02 & 0.27 & 0.34 & 3.87 \\
\hline 6 & Chanza & 0.24 & 0.11 & 0.20 & 0.19 & 0.08 & 0.02 & 0.04 & 0.00 & 0.00 & 0.31 & 0.17 & 1.37 \\
\hline 7 & Corumbel & 0.25 & 0.07 & 0.20 & 0.39 & 0.08 & 0.03 & 0.08 & 0.00 & 0.00 & 0.28 & 0.26 & 1.64 \\
\hline 8 & Del Pino & 0.40 & 0.18 & 0.64 & 0.65 & 0.13 & 0.14 & 0.08 & 0.00 & 0.00 & 0.34 & 0.52 & 3.08 \\
\hline 9 & Dique I & 0.13 & 0.05 & 0.14 & 0.17 & 0.07 & 0.08 & 0.03 & 0.00 & 0.00 & 0.28 & 0.31 & 1.27 \\
\hline 10 & Dique II & 0.18 & 0.06 & 0.19 & 0.49 & 0.09 & 0.04 & 0.01 & 0.00 & 0.08 & 0.26 & 0.23 & 1.65 \\
\hline 11 & Garnacha & 0.20 & 0.04 & 0.22 & 0.26 & 0.10 & 0.03 & 0.03 & 0.00 & 0.02 & 0.40 & 0.27 & 1.57 \\
\hline 12 & Gossan & 34.25 & 6.31 & 9.50 & 10.71 & 0.13 & 0.45 & 1.29 & 0.01 & 0.00 & 0.39 & 0.45 & 63.49 \\
\hline 13 & Grande & 0.44 & 0.12 & 0.48 & 2.71 & 0.00 & 0.05 & 0.06 & 0.00 & 0.00 & 0.34 & 0.43 & 4.74 \\
\hline 14 & Herrerias & 0.36 & 0.08 & 0.09 & 0.51 & 0.09 & 0.04 & 0.03 & 0.09 & 0.01 & 0.26 & 0.19 & 1.74 \\
\hline 15 & Lagunazo & 0.94 & 0.17 & 0.24 & 0.47 & 0.13 & 0.07 & 0.04 & 0.00 & 0.01 & 0.32 & 0.347 & 2,067 \\
\hline 16 & La Joya & 0.36 & 0.53 & 0.38 & 0.39 & 0.15 & 0.03 & 0.02 & 0.00 & 0.00 & 0.35 & 0.22 & 2.43 \\
\hline 17 & Marismillas & $2,265.87$ & 207.05 & 81.16 & 35.22 & 0.77 & 0.94 & 7,064 & 1.85 & 0.11 & 0.56 & 0.06 & $2,601.24$ \\
\hline 18 & Sancho & 4.96 & 2.32 & 3.89 & 3.95 & 1.49 & 0.13 & 0.38 & 0.37 & 0.01 & 0.33 & 0.44 & 18.27 \\
\hline 19 & Silillos I & 1.44 & 0.74 & 0.21 & 0.36 & 0.16 & 0.03 & 0.04 & 0.05 & 0.00 & 0.30 & 56.01 & 59.34 \\
\hline 20 & Silillos II & 0.51 & 0.56 & 0.15 & 0.18 & 0.18 & 0.02 & 0.04 & 0.01 & 0.00 & 0.30 & 0.41 & 2.34 \\
\hline 21 & Olivargas & 2.55 & 1.33 & 1.52 & 2.30 & 0.18 & 0.05 & 0.08 & 0.09 & 0.04 & 0.36 & 0.70 & 9.20 \\
\hline 22 & $\begin{array}{l}\text { Cueva de la } \\
\text { Mora }\end{array}$ & 15.80 & 2.31 & 111.52 & 17.66 & 0.23 & 0.39 & 0.70 & 0.01 & 0.00 & 0.54 & 0.47 & 149.64 \\
\hline 23 & Puerto León & 0.54 & 0.94 & 0.27 & 1.32 & 0.16 & 0.03 & 0.04 & 0.01 & 0.03 & 0.30 & 0.39 & 4.04 \\
\hline
\end{tabular}

data was submitted to statistical treatment using cluster analysis.

In this case, and after comparing various vicinity measures and different agglomeration methods, the 'Euclidean distance' was chosen as vicinity measure, and the 'Ward method' as agglomerative method. The Ward method or 'second-order central method' is a hierarchical method whose procedure is to calculate the average of all the variables for each cluster. Next, it calculates the Euclidean distance between each factor and the mean of its group. Then, it adds the distance for each case. At each stage, the clusters formed are those which produce the smallest increase in the total sum of the distances within the cluster (Bisquerra 1989). In this way, using this technique, the variables studied may be classified into different 'categories'. The vicinity measure used is the Euclidean distance, which is the square root of the sum of the differences between the variables squared. The reason for choosing the stated method and the vicinity measure is that they produce the clearest and most easily interpreted dendrograms.

Some of the most representative clusters obtained are presented below in the groups defined previously (Figures 3-5).

The relationship between electrical conductivity and TDS stands out in the clusters of variables for all the reservoirs 
(a) $\operatorname{TSD}(\mathrm{mg} / \mathrm{L})$

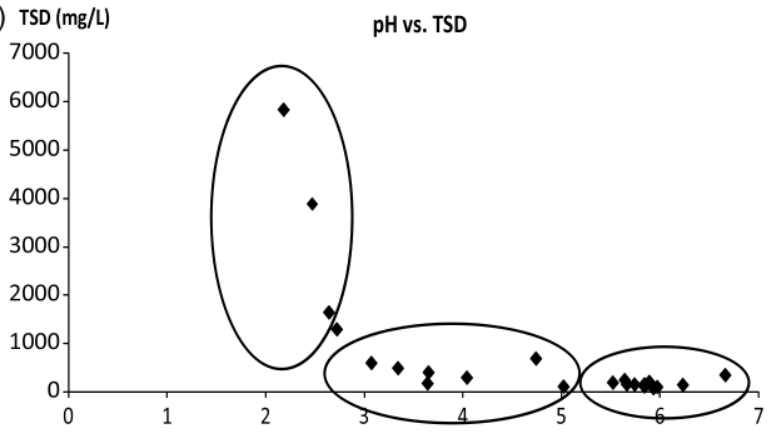

(b) $\mathrm{SO}_{4}{ }^{2-}(\mathrm{mg} / \mathrm{L})$

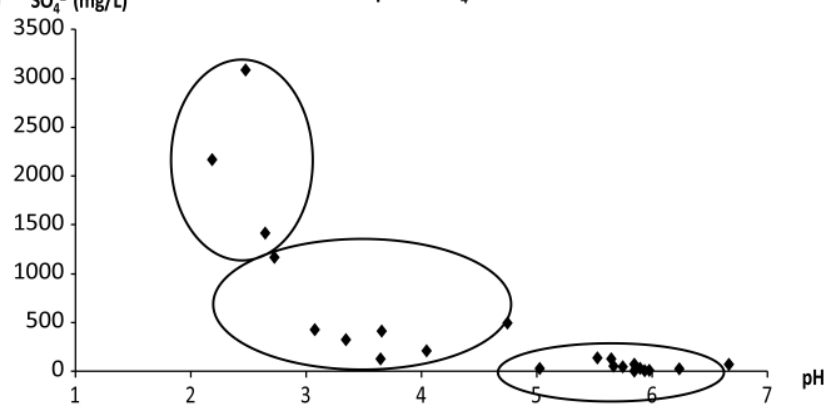

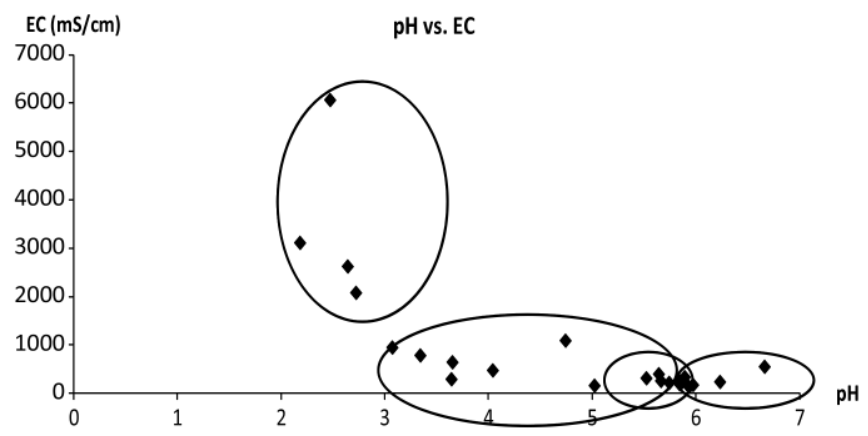

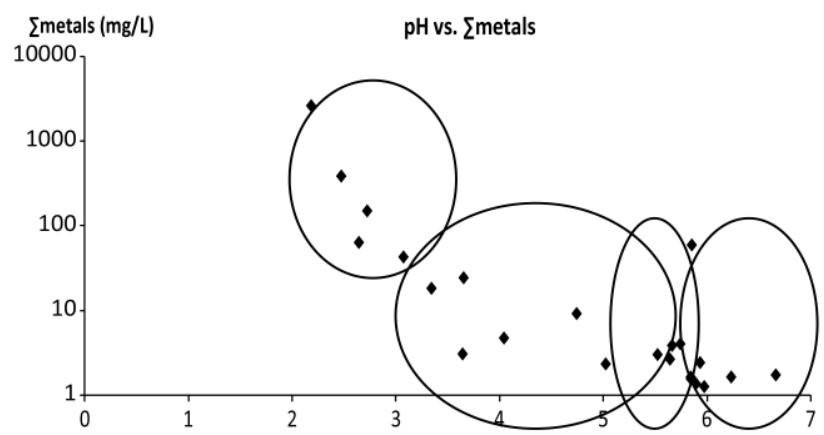

Figure 2 | (a) Scatter plot of $\mathrm{pH}-\mathrm{TDS}$ and $\mathrm{pH}-\mathrm{EC}$ for the average values measured in all the dams. (b) Scatter plot of $\mathrm{pH}_{-} \mathrm{SO}_{4}{ }^{2-}$ and $\mathrm{pH}-\sum$ metals for the average values measured in all the dams.

studied, with both linked to sulphates on occasions. The only reservoir where this relationship is not observed is in the Marismillas reservoir, where the variable pairs electrical conductivity-Pb and $\mathrm{pH}$-TDS can be observed.

All the clusters present two large differentiated groups, with a limited relationship between them for the different sampling points. That is to say, if we take the Agrio reservoir as an example, two main families are observed: that formed by the pair $\mathrm{Fe}-\mathrm{Pb}$ together with $\mathrm{Zn}$, As and $\mathrm{Sb}$, and another

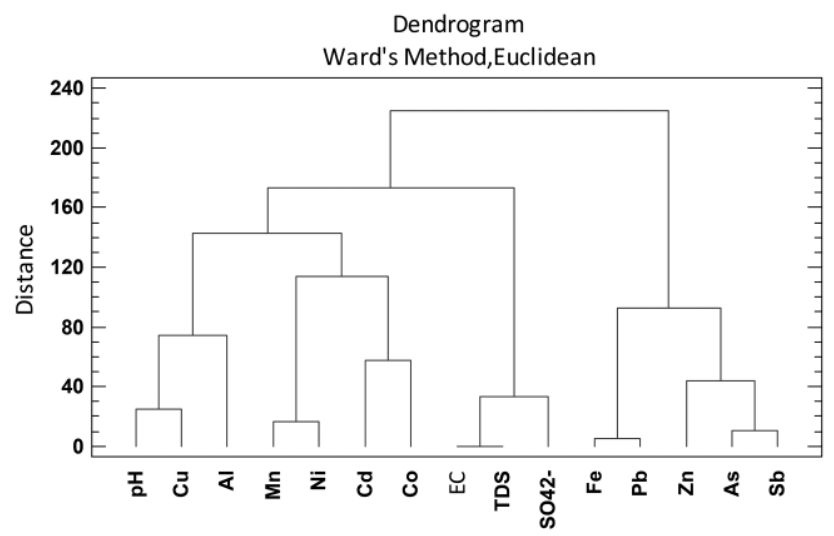

Figure 3 Dendrogram of variables for Agrio Dam. family in which the vicinity relation between electrical conductivity and TDS together with sulphates, and the associations between the remainder of the variables stand out.

\section{DISCUSSION}

By examining the average $\mathrm{pH}$ values measured, a classification of the sampling points was produced, creating a

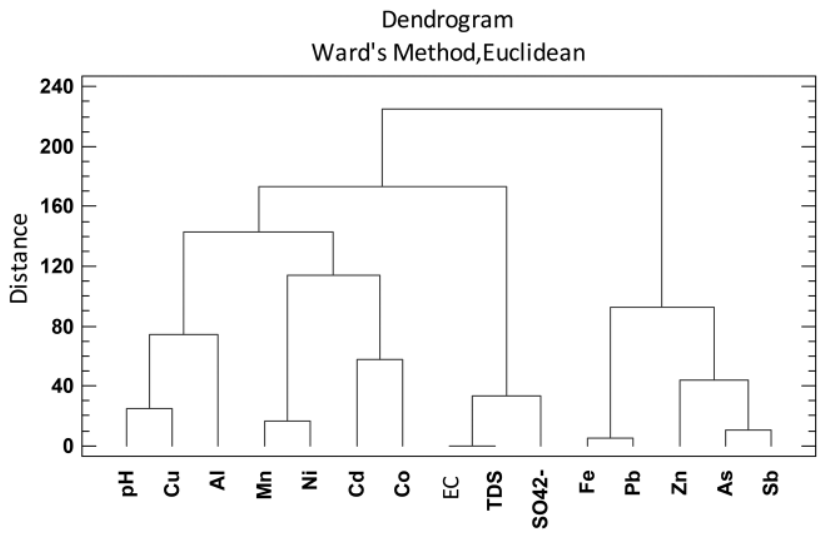

Figure 4 | Dendrogram of variables for Andévalo-Cobica Dam. 


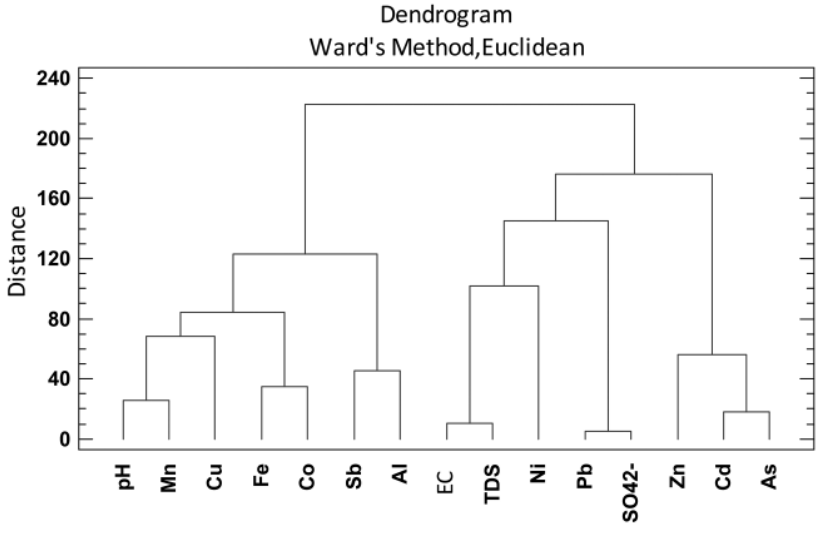

Figure 5 | Dendrogram of variables for Gossan Dam.

distinction between those reservoirs which present $\mathrm{pH}$ values $<3$, $\mathrm{pH}$ values between 3 and 5 and $\mathrm{pH}$ values $>5$.

The most acid reservoirs, with a $\mathrm{pH}<3$, are: Marismillas (pH: 2.18) < Aguas Ácidas (pH: 2.47)< Gossan (pH: 2.64) < Cueva de la Mora (pH: 2.72).

These reservoirs in turn present the highest average values analysed for electrical conductivity and TDS, as well as metals and sulphates.

A relationship is observed between the variables electrical conductivity and TDS in the clusters of variables obtained for the entry points of these reservoirs, with the Marismillas reservoir the only one where this grouping was not detected. The variable pairs electrical conductivity- $\mathrm{Pb}$ and $\mathrm{pH}-\mathrm{TDS}$ are observed in this reservoir, together with sulphates.

The reservoirs where average $\mathrm{pH}$ values between 3 and 5 could be measured were: Andévalo Cobica ( $\mathrm{pH}: 3.07)<$ Sancho (pH: 3.34) < Del Pino (pH: 3.64) < Andévalo Chorrito (pH: 3.65) < Grande (pH: 4.04) < Olivargas (pH: 4.74).

These reservoirs present average values for electrical conductivity, TDS, metals and sulphates.

There is also a direct relationship observed between electrical conductivity and TDS, on occasions linked to sulphates, Mn or As in the clusters of variables from these sampling points.

With average $\mathrm{pH}$ values higher than 5 we find the reservoirs Silillos II (pH: 5.02)< Agrio $(\mathrm{pH}: 5.52)<$ Lagunazo (pH: 5.64) < Campanario $(\mathrm{pH}: 5.66)<$ Puerto León $(\mathrm{pH}$ : 5.74) $<$ Garnacha $=$ Corumbel $(\mathrm{pH}: 5.84)<$ Silillos I $(\mathrm{pH}$ : $5.85)<$ Chanza (pH: 5.89) < La Joya $(\mathrm{pH}: 5.93)<$ Dique I (pH: 5.97) < Dique II (pH: 6.23) < Herrerías (pH: 6.66).
Low values for electrical conductivity, TDS, metals and sulphates are observed in these reservoirs.

In the clusters of variables for the entry points of these reservoirs the relationship electrical conductivity-TDS stands out, linked on some occasions to sulphates, $\mathrm{pH}, \mathrm{Cu}$, Ni or As.

\section{CONCLUSION}

It can be concluded that all the reservoirs present acid $\mathrm{pH}$ values with high concentrations of metals and sulphates, characteristic of processes of AMD. The reservoirs which present the most acid $\mathrm{pH}$ values are Marismillas, Aguas Ácidas, Gossan and Cueva de la Mora, presenting in turn the highest average values for electrical conductivity, TDS, sulphates and metals. There are also reservoirs whose waters possess values of $\mathrm{pH}>5$, close to neutral, with the lowest values recorded for electrical conductivity, TDS, metals and sulphates. The rest of the reservoirs have intermediate values, always with an inverse proportionality between $\mathrm{pH}$ and the rest of the parameters.

The clusters of variables reveal the direct relationship between electrical conductivity and TDS in all the reservoirs, except in the Marismillas reservoir. This fact may be due to the discharge of residual urban waters from the town of Nerva directly into the waters of the reservoir, which may mask the results obtained.

There are no common groupings observed for the rest of the parameters at the different sampling points, which is interpreted as a consequence of the great heterogeneity and geographical dispersion of the reservoirs studied, with each of them belonging to different river basins, each of which has its own particular characteristics. They are therefore also subject to the arrival of contributions contaminated by a variety of mineral parageneses and with very different levels of pollution controlled essentially by the clean contributions that cause dilution.

The fact that there is no overall pattern of behaviour for all the reservoirs analysed, in which the strong interdependency between electrical conductivity and TDS is maintained as a common exclusive factor, can be interpreted as a consequence of the coexistence of very different mineral parageneses throughout the IPB. This is 
in contrast to the homogeneous lithology of the adjoining rock in the reference domain. These huge paragenetic and therefore mineralogical differences, together with the diversity in size and ecological nature of the river basins and watersheds in the study, might produce the lack of geographical homogeneity of the redox potential, which would lead to the development of reactions that would give rise to the presence of the various elements in solution analysed.

\section{ACKNOWLEDGEMENT}

Financial support for this research was provided by DGCICYT National Plan, project no. CGL2010-21268C02-01.

\section{REFERENCES}

Amaral-Zettler, L. A., Zettler, E. R., Theroux, S. M., Palacios, C., Aguilera, A. \& Amils, R. 20II Microbial community structure across the tree of life in the extreme Río Tinto. ISME J. 5 (1), 42-50.

Bisquerra, R. 1989 Conceptual Introduction to Multivariate Analysis. Promoc Public Univ., Barcelona, SA.

Braungardt, C. B., Achterberg, E. P. \& Nimmo, M. I998 Behaviour of dissolved trace metals in the Rio Tinto/Rio Odiel estuarine system. In: European Land - Ocean Interaction Studies (J. A. Morales \& J. Borrego, eds). Seconds Annual Scientific Conference, Abstracts 51.

Braungardt, C. B., Achterberg, E. P., Elbaz-Poulichet, F. \& Morley, N. H. 2003 Metal geochemistry in a mine-polluted estuarine system in Spain. Appl. Geochem. 18 (11), 1757-1771.

Borrego, J., Morales, J. A., de la Torre, M. L. \& Grande, J. A. 2002 Geochemical characteristics of heavy metal pollution in surface sediments of the Tinto and Odiel river estuary southwestern Spain. Environ. Geol. 41, 785-796.

Cánovas, C. R., Hubbard, C. G., Olías, M., Nieto, J. M., Black, S. \& Coleman, M. L. 2008 Hydrochemical variations and contaminant load in the Río Tinto (Spain) during flood events. J. Hydrol. 350 (1-2), 25-40.

Casiot, C., Egal, M., Elbaz-Poulichet, F., Bruneel, O., BanconMontigny, C., Cordier, M. A., Gomez, E. \& Aliaume, C. 2009 Hydrological and geochemical control of metals and arsenic in a Mediterranean river contaminated by acid mine drainage the Amous River (France); preliminary assessment of impacts on fish Leuciscus cephalus. Appl. Geochem. 24 (5), 787-799.

Couceiro, M. A. \& Schettini, C. A. 2oIo Assessment of the suspended sediment dynamics of the Araranguá river estuary
SC Possible effects of acid drainage from the coal mining activity. Geociencias 29 (2), 251-266.

Davis, A. C., Patterson, B. M., Grassi, M. E., Robertson, B. S., Prommer, H. \& Mckinley, A. J. 2007 Effects of increasing acidity on metal loid) bioprecipitation in groundwater: Column studies. Environ. Sci. Technol. 41 (20), 7131-7137.

De la Torre, M. L., Grande, J. A., Jiménez, A., Borrego, J. \& Díaz Curiel, J. M. 2009 Time evolution of an AMD-affected river chemical makeup. Water Resour. Manage. 23 (7), 1275-1289.

Egal, M., Casiot, C., Morin, G., Elbaz-Poulichet, F., Cordier, M. A. \& Bruneel, O. 2010 An update insight into the natural attenuation of As concentrations in Reigous Creek southern France. Appl. Geochem. 25 (12), 1949-1957.

Elbaz-Poulichet, F., Morley, N. H., Cruzado, A., Velasquez, Z., Achterberg, E. P. \& Braungardt, C. B. 1999 Trace metal and nutrient distribution in an extremely low $\mathrm{pH}(2,5)$ riverestuarine system, the Ría of Huelva South-west Spain. Sci. Total Environ. 227, 73-83.

Elbaz-Poulichet, F., Dupuy, C., Cruzado, A., Velasquez, Z., Achterberg, P. \& Braungardt, C. 2000 Influence of sorption proceses by iron oxides and algae fixation on arsenic and phosphate cycle in an acidic estuary Tinto river, Spain. Water Res. 3412, 3222-3230.

Elbaz-Poulichet, F., Braungardt, C., Achterberg, E., Morley, N., Cossa, D., Beckers, J., Nomérange, P., Cruzado, A. \& Leblanc, M. 200I Metal biogeochemistry In the Tinto-Odiel rivers (Southern Spain) and in the Gulf of Cadiz: a synthesis of results of TOROS project. Cont. Shelf Res. 21 (18-19), 1961-1973.

Grande, J. A. 20II Impact of AMD processes on the public water supply: Hydrochemical variations and application of a classification model to a river in the Iberian Pyritic Belt (SW Spain). Hydrol. Res. 42 (6), 472-478.

Grande, J. A., Borrego, J. \& Morales, J. A. 2000 Study of heavy metal pollution in the Tinto-Odiel estuary in Southwestern Spain using spatial factor analysis. Environ. Geol. 39 (10), 1095-1101.

Grande, J. A., Borrego, J., Morales, J. A. \& de la Torre, M. L. 2003a A description of how metal pollution occurs in the TintoOdiel ria (Huelva-Spain) through the application of cluster analysis. Mar. Pollut. Bull. 46, 475-480.

Grande, J. A., Borrego, J., de la Torre, M. L. \& Sáinz, A. 200zb Application of cluster analysis to the geochemistry zonation of the estuary waters in the Tinto and Odiel rivers Huelva, Spain. Environ. Geochem. Health 25, 233-246.

Grande, J. A., Beltrán, R., Sáinz, A., Santos, J. C., de la Torre, M. L. \& Borrego, J. 2005a Acid mine drainage and acid rock drainage processes in the environment of Herrerías Mine Iberian Pyrite Belt, (Huelva-Spain) and impact on the Andevalo dam. Environ. Geol. 47, 185-196.

Grande, J. A., Andújar, J. M., Aroba, J., de la Torre, M. L. \& Beltrán, R. 2005b Precipitation, pH and metal load in AMD river basins: an application of fuzzy clustering algorithms to the process charcaterization. J. Environ. Monit. 74, 325-334. 
Grande, J. A., de la Torre, M. L., Cerón, J. C., Beltrán, R. \& Gómez, T. 2oroa Overall hydrochemical characterization of the Iberian Pyrite Belt. Main acid mine drainage generating sources Huelva, SW Spain. J. Hydrol. 390, 123-130.

Grande, J. A., Andújar, J. M., Arobam, J., Beltrán, R., de la Torre, M. L., Cerón, J. C. \& Gómez, T. 2orob Fuzzy modelling of the spatial evolution of the chemistry in the Tinto river SW Spain. Water Resour. Manage. 24, 3219-3235.

Grande, J. A., Andújar, J. M., Aroba, J. \& de la Torre, M. L. zoIoc Presence of As in the fluvial network due to AMD processes in the Riotinto mining area SW Spain A fuzzy logic qualitative model. J. Hazard. Mater. 176 (1-3), 395-401.

Grande, J. A., Jiménez, A., Romero, S., de la Torre, M. L. \& Gómez, T. 2oIod Quantification of heavy metals from AMD discharged into a public wáter supply dam in the Iberian Pyrite Belt (SW Spain) using centered moving average. Water Air Soil Pollut. 212, 299-307.

Grande, J. A., Jiménez, A., Borrego, J., de la Torre, M. L. \& Gómez, T. 2oroe Relationships between conductivity and $\mathrm{pH}$ in channels exposed to acid mine drainage processes: study of a large mass of data using classical statistics. Water Resour. Manage. 24, 4579-4587.

Grande, J. A., Arobam, J., Andujar, J. M., Gómez, T., de la Torre, M. L., Borrego, J., Romero, S., Barranco, C. \& Santisteban, M. 20II Tinto versus Odiel: two AMD polluted rivers and an unresolved issue. An artificial intelligence approach. Water Resour. Manage. 25, 3575-3594.

Gray, N. F. \& Delaney, E. 20Io Measuring community response of bentic macroinvertebrates in an erosional river impacted by acid mine drainage by use of a simple model. Ecol. Indic. 10 (3), 668-675.

Gunn, J., Sarrazin-Delay, C., Wesolek, B., Stasko, A. \& SzkokanEmilson, E. 20Io Delayed recovery of benthic macroinvertebrate communities in junction Creek, Sudbury, Ontario, after the diversion of acid mine drainage. Human Ecol. Risk Assess. 16 (4), 901-912.

Hafs, A. W., Horn, C. D., Mazik, P. M. \& Hartman, K. J. 2010 Influences of acid mine drainage and thermal enrichment on stream fish reproduction and larval survival. Northeast. Natural. 17 (4), 575-592.

Hao, C., Wang, L., Gao, Y., Zhang, L. \& Dong, H. 20 oro Microbial diversity in acid mine drainage of Xiang Mountain sulfide mine, Anhui Province, China. Extremophiles 14 (5), 465-474.

Heijs, S. K. \& Van Gemerden, H. 2000 Microbiological and environmental variables involved in the sulfide buffering capacity along eutrophication gradient in a coastal lagoon Bassin d'Arcachon, France. Hydrobiologia 437, 121-131.

Hubbard, C. G., Black, S. \& Coleman, M. L. 2009 Aqueous geochemistry and oxygen isotope compositions of acid mine drainage from the Río Tinto, SW Spain, highlight inconsistencies in current models. Chem. Geol. 265 (3-4), 321-334.

Jiménez, A., Aroba, J., de la Torre, M. L., Andújar, J. M. \& Grande, J. A. 2009 Model of behaviour of conductivity versus $\mathrm{pH}$ in acid mine drainage water, based on fuzzy logic and data mining techniques. J. Hydroinform. 11 (2), 147-153.
Leblanc, M., Morales, J. M., Borrego, J. \& Elbaz-Poulichet, F. 2000 4,500-year-old mining pollution in southwestern Spain: longterm implications for modern mining pollution. Econ. Geol. 95, 655-662.

Leistel, J. M., Marcoux, E., Thieblemont, D., Quesada, C., Sanchez, A. \& Almodavar, G. I998 The volcanic hosted massive sulphide deposits of the Iberian Pyrite Belt. Mineral. Depos. 33, 2-30.

López-González, N., Borrego, J., Morales, J. A., Carro, B. \& Lozano-Soria, O. 2006 Metal fractionation in oxic sediments of an estuary affected by acid mine drainage south-western Spain. Estuar. Coast. Shelf Sci. 68 (1), 297-304.

Loredo, J., Petit-Domínguez, M. D., Ordóñez, A., Galán, M., Fernández-Martínez, R., Álvarez, R. \& Rucandio, M. I. 2010 Surface water monitoring in the mercury mining district of Asturias Spain. J. Hazard. Mater. 176 (1-3), 323-332.

Lyew, D. \& Sheppard, J. 20or Use of conductivity to monitor the treatment of acid mine drainage by sulphate-reducing bacteria. Water Res. 358, 2081-2086.

Ochieng, G. M., Seanego, E. S. \& Nkwonta, O. I. 20Io Impacts of mining on water resources in South Africa: A review. Sci. Res. Essays 52 (2), 3351-3357.

Palau, A. 2002 La sedimentación en embalses. Medidas preventivas y correctoras. Actas del I Congreso de Ingeniería Civil. Territ. Medio Ambient. 1, 847-856.

Pinedo-Vara, I. I963 Piritas de Huelva. Su historia, minería y aprovechamiento. Summa, Madrid, Spain.

Rickard, D. \& Morse, J. W. 2005 Acid volatile sulfide AVS. Mar. Chem. 97, 141-197.

Romero, F. M., Núñez, L., Gutiérrez, M. E., Armienta, M. A. \& Ceniceros-Gómez, A. E. 20II Evaluation of the potential of indigenous calcareous shale for neutralization and removal of arsenic and heavy metals from acid mine drainage in the Taxco mining area, Mexico. Arch. Environ. Contam. Toxicol. 60 (2), 191-203.

Ruiz, F., Borrego, J., González-Regalado, M. L., López-González, N., Carro, B. \& Abad, M. 2009 Interaction between sedimentary processes, historical pollution and microfauna in the Tinto estuary SW Spain. Environ. Geol. 58 (4), 779-783.

Sáez, R., Pascual, E., Toscano, M. \& Almodovar, G. I999 The Iberian type of volcanosedimentary massive sulphide deposits. Mineral. Deposit. 34, 549-570.

Sáinz, A. 1999 Estudio de la Contaminación Química de Origen Minero en El Río Odiel. PhD Thesis, University of Huelva.

Sáinz, A., Grande, J. A., de la Torre, M. L. \& López, N. $2000 a$ Análisis de la contaminación por AMD en la cuenca del río Odiel. Residuos 57, 91-98.

Sáinz, A., Grande, J. A. \& de la Torre, M. L. 20oob El Tinto y el Odiel: dos ríos para una reflexión. Tecnol. Agua 207, 28-35.

Sáinz, A., Grande, J. A., de la Torre, M. L. \& López, N. $2000 c$ Influencia de la fracción granulométrica de corte en los contenidos de metales pesados de los sedimentos del curso principal del río Odiel. Hidropres 26, 44-49. 
Sáinz, A., Grande, J. A., de La Torre, M. L. \& Sánchez-Rodas, D. 2002 Characterisation of sequential leachate discharges of mining waste rock dumps in the Tinto and Odiel rivers. $J$. Environ. Manage. 64, 345-353.

Sáinz, A., Grande, J. A. \& de la Torre, M. L. 2003 Odiel River, acid mine drainage and current characterisation by means of univariate analysis. Environ. Int. 29, 51-59.

Sáinz, A., Grande, J. A. \& de la Torre, M. L. 2004 Characterisation of heavy metal discharge into the Ria of Huelva. Environ. Int. 20, 557-566.

Sáinz, A., Grande, J. A. \& de la Torre, M. L. 2005 Application of a systemic approach to the study of pollution of the Tinto and Odiel rivers Spain. Environ. Monit. Assess. 102, 435-445.

Sarmiento, A. M. 2007 Estudio de la contaminación por drenajes ácidos de mina de las aguas superficiales en la cuenca del río Odiel SO España. PhD Thesis, Universidad de Huelva.
USEPA 1994 Acid Mine Drainage Prediction. US Environmental Protection Agency, Office of Solid Waste, EPA530-R-94-036.

Valente, T. M. \& Leal Gomes, C. 2007 The role of two acidophilic algae as ecological indicators of acid mine drainage sites. J. Iber. Geol. 33 (2), 283-294.

Vicente-Martorell, J. J., Galindo-Riaño, M. D., García-Vargas, M. \& Granado-Castro, M. D. 2008 Heavy metal speciation of estuarine sediments affected by acid mine drainage in the Tinto and Odiel estuary, Spain. Relationship to bioconcentration of fish tissues. Fres. Environ. Bull. 17 (10B), 1744-1754.

Wen, X. \& Allen, H. E. 1999 Mobilization of heavy metals from Le An River sediment. Sci. Total Environ. 227, 101-108.

Younger, P. L. 200I Mine water pollution in Scotland: Nature, extent and preventative strategies. Sci. Total Environ. 265 (1-3), 309-326.

First received 13 May 2013; accepted in revised form 16 October 2013. Available online 23 November 2013 